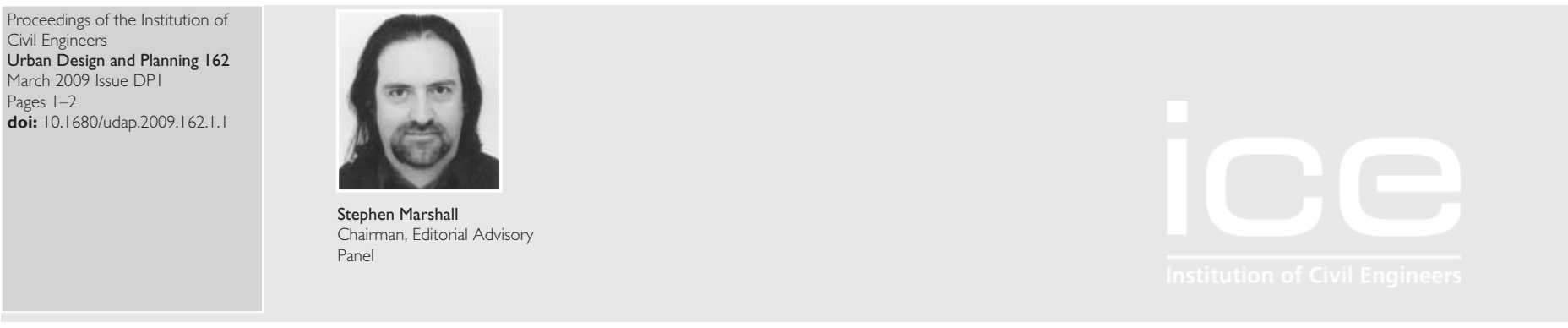

\title{
Global and local: making the connections
}

\section{S. Marshall PhD, DipUD, MCIT, MIHT}

The global nature of many of today's burning issues is not just a matter of geographical scale, but concerns the complexity of connections that can make problems seem intractable and outcomes unpredictable. A butterfly flapping its wings in a rainforest may be said to influence the weather on the other side of the world. The effects of 'toxic' mortgage products for certain American households trigger an international banking collapse. Wars, famines and outbreaks of disease routinely have societal side effects across continents. Meanwhile, the arrival of a certain new resident in 1600 Pennsylvania Avenue, Washington, sends palpable geopolitical ripples round the world.

In the urban sphere, we see global influences at play in the effects of international capital on investment decisions, international migration on local labour and housing markets, the need for cities to secure themselves against global terrorist threats, and the fortification of low-lying rural and urban areas against the possible effects of melting ice caps. Yet, despite recognising the global nature of these effects, their causes are typically made up of the aggregate of countless decisions and actions of individual people distributed through a multitude of localities.

The subject matter of Urban Design and Planning reflects a range of local and global relationships between the actions of professional urban designers and planners, actions and reactions of the public, connecting urban functioning to the wider world.

In this issue, Jon Lang discusses developments in urban design from an international perspective, considering the influence of international investors and design firms on shaping local places around the world. After a review of current paradigms of global urban design and design for locality, Lang suggests a neofunctional, ecological approach to urban design that could provide a way ahead for reconciling issues such as community, identity, sense of place and sustainability. ${ }^{1}$

At the local level, Morris et al. address the issue of car-free development (CFD) and suggest the potential for developing the link to community travel planning (CTP). Among other things, this article demonstrates the interplay between local urban aspects such as car ownership, physical design, communal facilities, planning regulations and accessibility in the urban context. $^{2}$
Also at the local level, Buchanan and Gay address the evaluation of local improvements to the design quality of streets, reporting on the results of two London studies exhibiting alternative approaches to valuing benefits: through stated preference (SP) and revealed preference (RP). Among other things, this article demonstrates specific local interlinkages between physical design, user perceptions of ambience and environmental quality, and perceived value signalled by property market prices. ${ }^{3}$

In this issue, also, we introduce 'Urbanwords', a new regular feature by Rob Cowan, that collates a variety of new and emerging words and their uses as applied to the urban context. In doing so, we wish to encourage awareness and articulation of new concepts and ideas in the field, as they emerge. $^{4}$

We do not expect all these terms to enter the common language of urbanism. While some may successfully propagate themselves, (or find adaptive re-use) others may prove to be ephemeral, or remain obscure. This linguistic 'survival of the fittest' is natural. Individually crafted neologisms cast into the public domain may sink or swim, while new coinages forged in the heat of everyday exchange may find a solid foothold in printed literature.

The Urbanwords entries consciously reflect both formal and informal use of language, whether by academics, practitioners, policymakers or the general public. Even buzzwords and jargon terms deserve exposure, whether to help demythologise them, pin them down or pass them on. The ongoing publication of this urban lexicon should not just help disseminate terms within their own disciplines, but in its own modest way could also help break down linguistic barriers between professions, between academia and practice, and between professionals and the public.

As professionals and members of the public, we all shape the future, whether through 'mall-walking' or 'vélopartage', 'shed-shifting' or 'skyfarming', 'ecotecture' or 'geoengineering'. Through a shared engagement with the issues of our time, articulated through a common understanding of urbanism, we can perhaps cooperate more effectively, making the right connections locally and globally to effect the necessary change. 


\section{REFERENCES}

1. LANG J. International urban design: theory and practice. Proceedings of the Institution of Civil Engineers: Urban Design and Planning, 162, No.1, 7-17.

2. Morris D., Enoch M., Pitfield D. and Ison S. Car-free development through UK community travel plans.
Proceedings of the Institution of Civil Engineers: Urban Design and Planning, 162, No.1, 19-27.

3. Buchanan, P. AND GAY, N. Making a case for investment in the public realm. Proceedings of the Institution of Civil Engineers: Urban Design and Planning, 162, No.1, 29-34.

4. Cowan, R. Urbanwords. Proceedings of the Institution of Civil Engineers: Urban Design and Planning, 162, No.1, 37-40. 